\title{
Religious Commitment and Paranormal Beliefs across Gender and Educational Stream
}

\author{
Adity Jamwal ${ }^{1 *}$, Chandra Shekhar ${ }^{2}$, Shamila Alam ${ }^{3}$
}

\section{ABSTRACT}

Religious Commitment is an “internal” quality that reflects the individual's self-rating on "religiousness" as well as the degree to which the individual seeks to follow religious teachings in everyday life, finds religion to be personally helpful, and gains personal strength by trusting in a higher power. Whereas paranormal phenomena are defined as events that violate the boundaries of current scientific belief. Religious commitment and paranormal beliefs share important qualities and generally are positively related. In the present study these variables were studied i.e. religious commitment and paranormal beliefs among University students. Purposive sampling technique was employed. 100 students from Jammu University,50 from each educational stream, i.e. from arts and science stream were taken. Religious commitment and paranormal belief was compared across the gender too. Results were non-significant between males and females in paranormal beliefs but significant results in both males and females in religious commitment was found. The results were significant among arts and science students in paranormal beliefs and non - significant in religious commitment. A positive relationship was found between religious commitment and paranormal beliefs.

Keywords: Religious commitment, paranormal beliefs, University Students, Gender.

Whereas spirituality is concerned with transcendent aspects of personal existence, and refers to personal, subjective aspect of religious experience. Religiosity involves thinking, feeling and behaving in accordance to doctrinal beliefs, which are endorsed in a religious institution. Religious commitment is a term loosely used to reflect level of religiosity. It attempts to capture how internally committed the person is to his religion. One of the best indicators of religious commitment is the estimation of intrinsic religious motivation or intrinsic religiosity, defined as the "degree to which a person adheres to his or her religious values, beliefs, and practices and uses them in daily living. In other words, religious commitment indicates the amount of time

\footnotetext{
${ }^{1}$ Research Scholar, P.G. Department of Psychology, University of Jammu, Jammu-Tawi

${ }^{2}$ Sr. Assistant Professor, P.G. Department of Psychology, University of Jammu, Jammu-Tawi

${ }^{3}$ P.G. student, P.G. Department of Psychology, University of Jammu, Jammu-Tawi

*Responding Author

(C) 2016 I A Jamwal, C Shekhar, S Alam; licensee IJIP. This is an Open Access Research distributed under the terms of the Creative Commons Attribution License (http://creativecommons.org/licenses/by/2.0), which permits unrestricted use, distribution, and reproduction in any Medium, provided the original work is properly cited.
} 
spent in private religious involvement, religious affiliation, the activities of religious organization and importance of religious beliefs which are practiced intrapersonal and interpersonal in daily living (Zawawi 2015). The word Paranormal was coined in late 1915 that mean- an experience that lies outside "the range of normal experience or Scientific Explanations. The term paranormal is used to describe the phenomenon, which if authentic -violate basic limiting principle of science. The question of why so many people, including the well educated, believe in the possibility of such phenomenon has perplexed the scientific community and as such the investigation of individual's differences in the belief in the paranormal has been a prominent avenue of psychological inquiry. Research has indicated that beliefs in the paranormal are associated with higher rather than the lower education and intelligence. Other findings suggest that belief in paranormal phenomena is not associated with the rejection of mainstream science or technology, at least among college and university students. Numerous researchers have looked toward demographics such as age, sex, and education level to explain differences in beliefs. Numerous studies indicate that there is a significant difference in beliefs in the paranormal between genders. Females have expressed stronger beliefs in the paranormal than males. Females were higher in their beliefs of ESP, and ghosts, while men had higher beliefs in UFOs and the Loch Ness Monster (Irwin, 1993). A study by Aarnio and Lindema (2004) found relationship between religious and paranormal beliefs was positive among paranormal believers and skeptics but negative among religious people. Aarnio and Lindeman (2005) examined the connections between paranormal beliefs and educational level, discipline, length of education, gender, and analytical and intuitive thinking and found that university students had less paranormal beliefs than vocational school students, which was partially due to university students' stronger preference for analytical thinking. Women's higher intuitiveness and lower analytical thinking partially explained their higher amount of beliefs compared to men. South Korean and American college students were compared on paranormal beliefs, first in 1999 and then in 2009 both in Korea and in the United States. In 1999, Korean students showed higher scores than the United States students in every sub type of paranormal beliefs except for religious belief. In 2009, Korean students showed higher scores in paranormal beliefs except for religiosity and spiritualism Oh, Kim \& Oh (2011). Some studies suggest that a person inclined to religious beliefs is also susceptible to paranormal beliefs, and vice versa (Goode, 2000).

\section{RESEARCH METHODOLOGY}

Variables

\section{Independent variables}

Gender

Educational Stream (Arts \&Science)

\section{Dependent variables}

Religious Commitment

Paranormal Beliefs 


\section{Religious Commitment and Paranormal Beliefs across Gender and Educational Stream}

\section{Objectives}

- To assess the level of Religious Commitment and Paranormal Beliefs among Gender.

- To assess the levels of Religious commitment and Paranormal Beliefs among Educational stream (Science and Arts).

- To Assess the Relationship between Religious Commitment and Paranormal Belief among University Students.

\section{Hypotheses}

- There will be a significant difference in the level of Religious Commitment and Paranormal Beliefs among Gender.

- There will be a significant difference in the level of Religious Commitment and Paranormal Beliefs among Educational Stream.

- There will be a relationship between Religious Commitment and Paranormal Belief among University Students.

\section{Sample}

The purposive sampling consisted of 100 people from University of Jammu consisting of 50 from each educational stream i.e. from arts and science stream. Thereby again dividing into2 segments 25 females (Arts) and 25 males (Arts) and 25 females (science) and 25 males (science).

\section{Tools}

1. The Religious Commitment Inventory-10(RCI-10; Worthington et.al., 2003) describes the level of one's religious commitment. That is, it is used to assess the degree to which a person adheres to his or her religious values, beliefs, and practices and uses them in daily living. RCI subscales measure intrapersonal religious commitment with 6 items, and interpersonal religious commitment with 4 items. Thus, RCI-10 consists of a total of 10 items rated on a five point scale from $1=$ Not at all true of me to $5=$ totally true of me. All items of Intrapersonal religious commitment had factor loadings of .59 or above and those of Interpersonal religious commitment had factor loadings of .62 or above. The coefficient alphas were .93 for the full scale, .92 for Intrapersonal Religious Commitment, and .87 for Interpersonal Religious Commitment (Worthington et al., 2003).

2. Paranormal belief. The Revised Paranormal Belief Scale contains 26 items with a 7-point rating scale for each statement (1=strongly agree and $7=$ strongly disagree). Responses are taken at face value, aside from number 23 whose response is reversed, and added together to determine the score. The revised version of this scale has been shown to have higher reliability and validity than its predecessor and also an increased cross-cultural validity (Tobacyk, 2004).The Revised Paranormal Belief Scale measures7 aspects of paranormal belief: traditional religious belief, psi, witchcraft, superstition, spiritualism , extraordinary life forms, and precognition.

\section{RESULTS}

The current study was conducted to assess the level of religious commitment and paranormal beliefs among university students. After the collection of data and scoring, statistical analysis 
was done to test the formulated hypothesis of the study. The results have been discussed below:

Table-1 Mean, SD and t-test of Male and Female students of paranormal beliefs

\begin{tabular}{|c|c|c|c|c|c|c|}
\hline VARIABLES & GENDER & $\mathbf{N}$ & Mean & SD & $\mathbf{T}$ & $\begin{array}{l}\text { Sig. }(2- \\
\text { tailed) }\end{array}$ \\
\hline \multirow{2}{*}{$\begin{array}{l}\text { Traditional Religious } \\
\text { beliefs }\end{array}$} & MALE & 50 & 5.705 & 1.637 & \multirow{2}{*}{0.672} & \multirow{2}{*}{0.503} \\
\hline & FEMALE & 50 & 5.505 & 1.324 & & \\
\hline \multirow{2}{*}{ PSI } & MALE & 50 & 3.895 & 1.101 & \multirow{2}{*}{0.963} & \multirow{2}{*}{0.338} \\
\hline & FEMALE & 50 & 3.675 & 1.182 & & \\
\hline \multirow{2}{*}{ Witch craft } & MALE & 50 & 3.465 & 1.487 & \multirow{2}{*}{$\begin{array}{l}- \\
3.522\end{array}$} & \multirow{2}{*}{0.001} \\
\hline & FEMALE & 50 & 4.375 & 1.061 & & \\
\hline \multirow{2}{*}{ Superstition } & MALE & 50 & 2.979 & 1.464 & \multirow{2}{*}{$\begin{array}{l}- \\
2.634\end{array}$} & \multirow{2}{*}{0.010} \\
\hline & FEMALE & 50 & 3.680 & 1.181 & & \\
\hline \multirow{2}{*}{ Spiritualism } & MALE & 50 & 3.743 & 1.129 & \multirow{2}{*}{1.656} & \multirow{2}{*}{0.101} \\
\hline & FEMALE & 50 & 3.395 & 0.969 & & \\
\hline \multirow{2}{*}{ Extra ordinary life farms } & MALE & 50 & 3.853 & 1.042 & \multirow{2}{*}{0.424} & \multirow{2}{*}{0.673} \\
\hline & FEMALE & 50 & 3.766 & 1.002 & & \\
\hline \multirow{2}{*}{ Pre Cognition MOI } & MALE & 50 & 3.880 & 1.111 & \multirow{2}{*}{$\begin{array}{l}- \\
1.520\end{array}$} & \multirow{2}{*}{0.132} \\
\hline & FEMALE & 50 & 4.180 & 0.844 & & \\
\hline \multirow{2}{*}{ Total } & MALE & 50 & 27.520 & 4.394 & \multirow{2}{*}{$\begin{array}{l}- \\
-1.218\end{array}$} & \multirow{2}{*}{0.226} \\
\hline & FEMALE & 50 & 28.576 & 4.269 & & \\
\hline
\end{tabular}

Table- 1 shows the mean, SD, t-values and p-values on all the 7 dimensions of paranormal beliefs of both Male and Female students. Mean and SD on the dimensions of Traditional Religious beliefs, PSI, Witch craft, Superstition, Spiritualism, Extra ordinary life farms and Pre Cognition MOI. Mean for Male is 5.705, 3.895, 3.465, 2.979, 3.743, 3.853, 3.880 and total is 27.520 and SD for male is $1.637,1.101,1.487,1.464,1.129,1.042,1.111$ and total is 4.394 respectively. Mean and SD of Female students is 5.505, 3.675, 4.375, 3.680, 3.395, 3.766 , 4.180 and total is 28.576 and SD is 1.324, 1.182, 1.061, 1.181, $0.969,1.002,0.844$ and Total is 4.269 respectively. The t- value and P-value, of both Male and Female students came out to be t-value is0.672, $0.963,-3.522,-2.634,1.656,0.424,-1.520$ and total -1.218 and p-value is $0.503,0.338,0.001$, $0.010,0.101,0.673,0.132$ and total 0.226 which indicates that traditional religious beliefs, PSI , Spiritualism and pre-cognition MOI and extra ordinary life farms are non-significant while other dimensions viz. Witch craft and Superstition are significant. And the total result is nonsignificant.

Table-2 Mean, SD and t-test of Male and Female students of Religious Commitment

\begin{tabular}{|l|l|l|l|l|l|l|}
\hline VARIABLES & GENDER & $\mathbf{N}$ & Mean & SD & T & Sig. (2-tailed) \\
\hline $\begin{array}{l}\text { Religious } \\
\text { Commitment }\end{array}$ & MALE & 50 & 31.080 & 5.371 & \multirow{2}{*}{3.952} & \multirow{2}{*}{0.000} \\
\cline { 2 - 6 } & FEMALE & 50 & 27.060 & 4.783 & & \\
\hline
\end{tabular}


Table-2 Mean, SD and t-test of Male and Female students in religious commitment. Mean of Male students is 31.080 and SD is 5.371Mean of Female students is 27.060 and SD is 4.783.The t-value and P-value of both Male and Female students came out to be 3.952 and 0.000 respectively, which indicates that the results are significant.

Table-3 Mean, SD and t-test of Arts and Science students on seven dimensions of Paranormal Beliefs

\begin{tabular}{|c|c|c|c|c|c|c|}
\hline VARIABLES & STREAMS & $\mathbf{N}$ & Mean & SD & $\mathbf{T}$ & Sig. (2-tailed) \\
\hline \multirow{2}{*}{$\begin{array}{l}\text { Traditional Religious } \\
\text { beliefs }\end{array}$} & ARTS & 50 & 4.980 & 1.535 & \multirow[b]{2}{*}{ 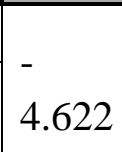 } & \multirow[b]{2}{*}{0.000} \\
\hline & SCIENCE & 50 & 6.230 & 1.140 & & \\
\hline \multirow{2}{*}{ PSI } & ARTS & 50 & 3.800 & 1.206 & \multirow{2}{*}{0.131} & \multirow{2}{*}{0.896} \\
\hline & SCIENCE & 50 & 3.770 & 1.085 & & \\
\hline \multirow{2}{*}{ Witch craft } & ARTS & 50 & 3.850 & 1.508 & \multirow{2}{*}{$\begin{array}{l}- \\
-511\end{array}$} & \multirow{2}{*}{0.610} \\
\hline & SCIENCE & 50 & 3.990 & 1.215 & & \\
\hline \multirow{2}{*}{ Superstition } & ARTS & 50 & 2.786 & 1.402 & \multirow{2}{*}{$\begin{array}{l}- \\
4.306\end{array}$} & \multirow{2}{*}{0.000} \\
\hline & SCIENCE & 50 & 3.873 & 1.104 & & \\
\hline \multirow{2}{*}{ Spiritualism } & ARTS & 50 & 3.595 & 1.187 & \multirow{2}{*}{0.242} & \multirow{2}{*}{0.809} \\
\hline & SCIENCE & 50 & 3.543 & 0.931 & & \\
\hline \multirow{2}{*}{ Extra ordinary life farms } & ARTS & 50 & 3.773 & 1.183 & \multirow{2}{*}{$\begin{array}{l}- \\
0.353\end{array}$} & \multirow{2}{*}{0.725} \\
\hline & SCIENCE & 50 & 3.845 & 0.831 & & \\
\hline \multirow{2}{*}{ Pre Cognition MOI } & ARTS & 50 & 3.945 & 1.140 & \multirow{2}{*}{$\begin{array}{l}- \\
0.855\end{array}$} & \multirow{2}{*}{0.395} \\
\hline & SCIENCE & 50 & 4.115 & 0.824 & & \\
\hline \multirow{2}{*}{ Total } & ARTS & 50 & 26.729 & 5.224 & \multirow{2}{*}{\begin{tabular}{|l} 
\\
3.172
\end{tabular}} & \multirow{2}{*}{0.002} \\
\hline & SCIENCE & 50 & 29.367 & 2.694 & & \\
\hline
\end{tabular}

Table- 3 shows the mean, SD, t-values and p-values on all the 7 dimensions of paranormal beliefs of both Arts and science students. Mean and SD on the dimensions of Traditional Religious beliefs, PSI, Witch craft, Superstition, Spiritualism, Extra ordinary life farms and Pre Cognition MOI. Mean for Arts students is 4.980, 3.800, 3.850,2.786, 3.595, 3.773, 3.945 and total is 26.729 and SD for Arts is 1.535, 1.206, 1.508, 1.402, 1.187, 1.183, 1.140 and total is 5.224respectively. Mean and SD of science students is $6.230,3.770,3.990,3.873,3.543$, 3.845 , 4.115 and total is 29.367 and SD is $1.140,1.085,1.215,1.104,0.931,0.831,0.824$ and Total is 2.692 respectively. The t- value and P-value, of both Arts and science students came out to be tvalue is -4.622, $0.131,-0.511,-4.306,0.242,-0.353,-0.855$ and total 3.172 and p-value is $0.000,0.896,0.610,0.000,0.809,0.725,0.395$ and total 0.002 which indicates that PSI , Witch craft, Spiritualism, pre-cognition MOI, extra ordinary life farms are non-significant while other 
dimensions viz. Traditional religious belief and Superstition are significant. And the results are significant.

Table-4 Mean, SD and t-test of Arts and Science Students of Religious Commitment.

\begin{tabular}{|l|l|l|l|l|l|l|}
\hline VARIABLES & STREAMS & N & Mean & SD & T & $\begin{array}{l}\text { Sig. (2- } \\
\text { tailed) }\end{array}$ \\
\hline $\begin{array}{l}\text { Religious } \\
\text { Commitment }\end{array}$ & ARTS & 50 & 28.560 & 5.747 & \multirow{2}{*}{-0.936} & 0.352 \\
\cline { 2 - 6 } & SCIENCE & 50 & 29.580 & 5.139 & \\
\hline
\end{tabular}

Table-4 Mean, SD and t-test of Arts and science students in religious commitment. Mean of Arts students is 28.560 and SD is 5.747 Mean of science students is 29.580 and SD is 5.139 . The tvalue and P-value of both Arts and science students came out to be -0.936 and 0.352 respectively, which indicates that the results are non-significant.

Correlation Table

\begin{tabular}{|l|l|l|l|}
\hline Variable & Parameter & $\begin{array}{l}\text { Religious } \\
\text { Commitment }\end{array}$ & Paranormal Beliefs \\
\hline Religious Commitment & $\begin{array}{l}\text { Pearson correlation } \\
\text { Sig(2 tailed) }\end{array}$ & 1 & $\begin{array}{l}0.329 * * \\
0.001 \\
100\end{array}$ \\
\hline Paranormal Beliefs & $\mathrm{N}$ & 100 & 1 \\
& & $0.329^{* *}$ & 100 \\
& & 0.001 & \\
\hline
\end{tabular}

Correlation is significant at the 0.01 level (2-tailed).

\section{DISCUSSION:}

The Present study was conducted to measure the level of Religious commitment and paranormal beliefs among university students. The first objective of the study was to assess the level of religious commitment and paranormal beliefs in male and female students. On all the dimensions of paranormal beliefs i.e. Traditional Religious belief ,PSI, Witch craft, Superstition, Spiritualism, Extra ordinary life farms and Pre cognition. Significant differences were obtained in which craft and superstition, And Non-significant in PSI, traditional religious belief, extra ordinary life farms, spiritualism, and pre cognition. In the total of all the dimensions, the results were non-significant between males and females in paranormal beliefs. And the results of religious commitment are significant in both males and females. Therefore, the alternate hypothesis i.e. there will be non-significant difference in religious commitment and paranormal beliefs in university students, is rejected.

The second objective of the study was to assess the level of Religious commitment and paranormal belief in arts and science students of university on all the dimensions of paranormal beliefs the results are significant in traditional religious belief, superstition and non-significant in 
Psi, pre cognition Witch craft, spiritualism, extra ordinary life farms in the total of all the dimensions the results are significant between arts and science students. And the results of religious commitment are non-significant. Therefore, the alternate hypothesis i.e. there will be a non-significant difference religious commitment and paranormal beliefs in arts and science students of university, is rejected.

The third objective of the study was to examine the relationship between religious commitment and paranormal beliefs among the University student, and the strong positive relationship was found between religious commitment and paranormal beliefs. Therefore, the alternate hypothesis is accepted as there was a relationship between religious commitment and paranormal beliefs. Mean of female students in paranormal beliefs is more than males which means that females students have more beliefs on paranormal. And in case of religious commitment males students have more beliefs on religion. In case of arts and science students, mean of both paranormal belief and religious commitment is more in science students. The studies which support our hypotheses are i.e. Numerous researchers have looked toward demographics such as age, sex, and education level to explain differences in beliefs. Numerous studies indicate that there is a significant difference in beliefs in the paranormal between genders. Females have expressed stronger beliefs in the paranormal than males. Females were higher in their beliefs of ESP, and ghosts, while men had higher beliefs in UFOs and the Loch Ness Monster (Irwin, 1993). Blackmore (1997) found that there was a large significant sex difference between believers and non-believers. Blackmore found that over 70 percent of the female respondents were believers, compared to 48 percent of the males. The education level of participants is also considered when investigating belief systems. Another study suggests that religious and paranormal beliefs are negatively connected or independent of each other (Donahue, 1993; MacDonald, 2000; Rice, 2003).

\section{CONCLUSION}

The present study was conducted on seven dimensions i.e. Traditional Religious belief , PSI, Witch craft, Superstition, Spiritualism, Extra ordinary life farms and Pre cognition to measure the level of Religious commitment and paranormal beliefs among university students in male/female students and arts/science students, on all the total dimensions the results were nonsignificant between males and females in paranormal beliefs but significant results in both males and females in religious commitment was found. The results are significant among arts and science students in paranormal beliefs and non-significant in religious commitment.

\section{REFERENCE}

Arnio,k .\& Lindeman,M.(2004).Religious people and paranormal believers. Journal of individual difference.http://www.dx.doi.org/10.1027.

Arnio,k. \& Lindeman,M.(2005).Paranormal beliefs, education, and thinking styles. Personality and individual differenc .39(7).

Blackmore, S. (1997). Parapsychology: Sex differences. British Journal of Psychology, 88, 683694. 


\section{Religious Commitment and Paranormal Beliefs across Gender and Educational Stream}

Donahue, M.J. (1993). Prevalence and correlates of New Age beliefs in six protestant denominations. Journal for the Scientific Study of Religion, 32, 177-184.

Goode, E. (2000). Paranormal beliefs. A sociological introduction. Prospect Heights, IL: Waveland Press.

Irwin, Harvey J. 1993. Belief in the paranormal: A review of the empirical literature. The Journal of the American Society for Psychical Research.

http://www.paranormalsociety.com/paranormal evidence.

MacDonald, D.A. (2000). Spirituality: Description, measurement, and relation to the five-factor model of personality. Journal of Personality, 68, 153-197

Oh,J.,Kim,K.R.,Oh,S.(2011).Difference and Changes in paranormal beliefs in university students from south korea and the united states.Korean Social science journal.38(2).http://www.kossrec.org/wp-content/uploads/2015/04/02-kssj-11-02-04.pdf

Rice, T.W. (2003). Believe it or not: Religious and other paranormal beliefs in the United States. Journal for the Scientific Study of Religion, 42, 95-106.

Tobacyk, J. J. (2004). A revised paranormal belief scale. The International Journal of Transpersonal Studies, 23, 94-98

Worthington, E., Wade, N., Hight, T., Ripley, J., McCullough, M., Berry, J.,Bursley, K., \& O'Connor, L. (2003). The Religious Commitment Inventory-10: Development, refinement, and validation of a brief scale for research and counseling. Journal of Counseling Psychology, 50 (1), 84-96.

Zawawi,J.(2015).Religious Commitment And Psychological Well-Being: Forgiveness As A Mediator.European scientific journal.11(5) 